\title{
Monoterpenoid Content of Pygmy Rabbit Stomach Ingesta
}

\author{
SUSAN M. WHITE, BRUCE L. WELCH, AND JERRAN T. FLINDERS
}

\begin{abstract}
During mid-January 1979, ingesta samples were collected from the stomachs of ten wild pygmy rabbits. The ingesta samples were analyzed for big sagebrush and monoterpenoid content. Big sagebrush comprised $97 \%$ of the material in the ingesta and was the only forage containing monoterpenoids. Monoterpenoid content of the ingesta was only $23 \%$ of expected levels. This major loss (77\%) of monoterpenoids may occur during mastication. Loss of monoterpenoids from mastication by pygmy rabbits was measured in an airtight rabbit chamber. Twelve times more monoterpenoids were recovered during the rabbit feeding trials (big sagebrush and rabbit) than during the control tests (big sagebrush only).
\end{abstract}

Recent dietary studies indicate that pygmy rabbits (Brachlagus idahoensis) have a near obligate relationship with sagebrush (Artemisia sp.) (Green and Flinders 1980). Green and Flinders (1980) and Wilde (1978) found $99 \%$ of the winter diet of pygmy rabbits was sagebrush. Only the sage grouse (Centrocercus urophasianus) and some wintering populations of mule deer(Odocoileous hemionus) and antelope (Antilocapra americana) depend on big sagebrush to the degree pygmy rabbits do (Kufeld et al. 1973; Sundstrom et al. 1973; Braun et al. 1977).

Sagebrush contains monoterpenoids (volatile oils) that exhibit antimicrobial properties (Nagy and Regelin 1977). These properties are postulated to reduce microbial digestion in ruminants (Longhurst et al. 1968; Radwan 1974). Values ranging from 15 to $50 \%$ sagebrush in the diets of deer are said to cause digestive disturbances, and in some cases sufficient to cause death in deer (Nagy et al. 1964; Nagy and Tengerdy 1968; Wallmo et al. 1977; Carpenter et al. 1979). Welch and McArthur (1981) and Welch and Pederson (1981) questioned whether monoterpenoids cause digestive disturbances in mule deer. Welch and Pederson (1981) hypothesized that through volatilization during mastication and ingestion, mule deer could greatly reduce the interaction of monoterpenoids with rumen microorganisms. Cluff et al. (1982) found monoterpenoid levels in mule deer rumens were considerably lower than in forage consumed by the deer. Severson et al. (1968) reported that antelope may consume large amounts of big sagebrush (up to $90 \%$ of the diet) without apparent detrimental effects. The purpose of this study is to test the hypothesis that the monoterpenoid level in the stomach ingesta of pygmy rabbits is significantly less than expected from the forage ingested.

\section{Materials and Methods}

Pygmy rabbits inhabited a big sagebrush (Artemisia tridentata) and bitterbrush (Purshia tridentata) community located on the U.S. Sheep Experiment Station near Dubois, ldaho (Green and Flinders 1980 ). From this population, 10 pygmy rabbits were killed to determine monoterpenoid content of big sagebrush in the stomach ingesta. Rabbits were killed on January 12 and 13, 1979, and the

\footnotetext{
Authors are graduate research assistant, Range Science Department, Brigham Young University, Provo, Utah 84602; research plant physiologist, Intermountain Forest and Range Experiment Station, Shrub Sciences Laboratory, Provo, Utah 84601; and chairman, Botany and Range Science Department, Brigham Young University, Provo, Utah 84602 .

Manuscript received April 7, 1980.
}

stomachs immediately removed and frozen with dry ice. A composite, vegetative sample (current year's growth) of big sagebrush was collected at the same time and location where the rabbits were killed. Vegetative samples were also frozen with dry ice.

At the laboratory, stomach ingesta and sagebrush were immediately placed in a freezer $\left(-35^{\circ} \mathrm{C}\right)$ for storage. Stomach ingesta were removed from the stomach lining and weighed, and reingested food pellets were separated from other stomach contents. Reingested pellets or soft feces are products of the cecum; the rabbit takes them directly from the anus and swallows them whole (Moir 1968). Fourteen grams of stomach ingesta were placed in a $125 \mathrm{ml}$ erlenmeyer flask with $25 \mathrm{ml}$ of absolute ether and placed on a shaker for 20 hours. The ether extract was decanted from the stomach material into a $50 \mathrm{ml}$ volumetric flask with one $\mathrm{ml}$ of carvone standard $(31.25 \mathrm{~g} / 250 \mathrm{ml})$ and enough ether to bring to volume. Reingested pellets from the stomach were treated in the same manner except only 3 to $5 \mathrm{~g}$ of pellets were placed in ether with $.2 \mathrm{ml}$ of carvone standard, and ether extract was concentrated by reduced pressure to $10 \mathrm{ml}$.

The sagebrush samples were ground in liquid nitrogen and monoterpenoids extracted by Soxhlet extraction using absolute ether (Welch and McArthur 1981). All ether extracts were analyzed for monoterpenoids by gas chromatographic techniques outlined by Welch and McArthur (1981). Dry weights of all material (stomach and vegetative) were obtained to express monoterpenoid content on a dry weight basis.

Microscopic techniques as described by Flinders and Hansen (1972) were used to determine the relative percent frequency of sagebrush in the stomach ingesta of the 10 pygmy rabbits. These values were used to calculate the concentration of monoterpenoids, on a dry matter basis, in stomach ingesta.

One male pygmy rabbit, from a captive colony of rabbits at Brigham Young University, was used to measure loss of monoterpenoids through the ingestion processes. An airtight rabbit chamber, through which a constant flow of compressed air $(1,500$ $\mathrm{ml} /$ minute) could pass, was dêsigned to hold a rabbit and sagebrush. Air from the rabbit chamber passed through glass tubing and bubbled through two successive $500 \mathrm{ml}$ flasks containing 300 $\mathrm{ml}$ of absolute ether to trap the monoterpenoids. The flasks were placed in an ice bath to minimize ether evaporation.

Three tests were conducted under standard conditions. These conditions were: (1) on the first day at $6: 30$ a.m. a big sagebrush plant was selected, tagged, and current year growth sampled; (2) the sagebrush sample was immediately transported to the laboratory, where $50 \mathrm{~g}$ of sample was placed in the rabbit chamber with the rabbit; (3) the air was turned on at 7 a.m. and off at 1 p.m.; (4) ether from the flasks was concentrated to about $6 \mathrm{ml} ; .2 \mathrm{ml}$ of a carvone standard was added and then brought to a $10 \mathrm{ml}$ volume; (5) monoterpenoids were measured by gas chromatograph; (6) the next day, the same big sagebrush plant was again sampled at 6:30 a.m. and steps 3 through 5 repeated, except the rabbit was removed from the rabbit chamber (control).

These steps made up the first test. The next test began with the selection of a new big sagebrush plant. Temperature in the rabbit 
chamber remained constant $\left(24^{\circ} \mathrm{C}\right)$ throughout testing.

Throughout both tests, the rabbit chamber contained a dish of guinea pig pellets and a water bottle. Pygmy rabbits are negatively sensitive to extended periods without food (personal observation). The rabbit was not fasted except for test 3 , when all food was removed 12 hours prior to testing. To create minimal disturbance the rabbit stayed in the chamber for the duration of pretesting and testing, being removed only when sagebrush alone was tested.

The amount of trapped monoterpenoids from the three tests was expressed in milligrams. Paired comparisons were used to determine significant differences (Huntsberger 1967).

\section{Results}

Stomach ingesta of pygmy rabbits contained $97 \%$ sagebrush on a dry matter basis. Total monoterpenoid content for the big sagebrush plants being eaten by the pygmy rabbits was $2.94 \%$ dry matter. Total monoterpenoid content of pygmy rabbit stomach ingesta was $0.607 \%$ dry matter, and reingested pellets contained $0.048 \%$ dry matter; together this represents $77 \%$ less monoterpenoids than found in the big sagebrush plants being eaten. Individual monoterpenoid fractions of the ingesta showed a similar reduction in monoterpenoid levels as compared with the composite sagebrush sample (Table 1).

Table 1. Summary of monoterpenoid fractions found in fresh big sagebrush and in rabbit stomach ingesta, expressed as percent dry matter.

\begin{tabular}{|c|c|c|c|c|}
\hline $\begin{array}{l}\text { Monoterpenoid } \\
\text { fractions }\end{array}$ & $\begin{array}{c}\text { Fresh } \\
\text { sagebrush }\end{array}$ & $\begin{array}{l}\text { Stomach } \\
\text { content }\end{array}$ & $\begin{array}{l}\text { Reingested } \\
\text { pellets }\end{array}$ & $\begin{array}{l}\text { Percent } \\
\text { mono- } \\
\text { terpenoids } \\
\text { lost from } \\
\text { stomach! }\end{array}$ \\
\hline Pinene & .03 & .013 & .000 & 55.3 \\
\hline Camphene & .08 & .023 & .002 & 67.8 \\
\hline 1,8-Cineol & .25 & .015 & .000 & 93.8 \\
\hline D-Camphor & .44 & .084 & .025 & 75.2 \\
\hline Unknowns & 2.14 & .472 & .021 & 76.3 \\
\hline Total & 2.94 & .607 & .048 & 77.0 \\
\hline
\end{tabular}

'(Stomach + pellets)

0.97

$=$ Percent of monoterpenoids remaining in stomach.

Amount of monoterpenoids in big sagebrush

$100-$ percent remaining $=$ Percent monoterpenoids lost from stomach .

0.97 is the proportion of big sagebrush found in the stomach.

Total trapped monoterpenoids for sagebrush alone from the rabbit chamber and for sagebrush and the rabbit were $.53 \mathrm{mg}$ and $6.66 \mathrm{mg}$ respectively (Table 2 ). $\alpha$-Pinene content for sagebrush alone was $0 \mathrm{mg}$ and with the rabbit was $0.07 \mathrm{mg}$. With sagebrush alone in the chamber, no camphene was recovered, while $1.07 \mathrm{mg}$ of camphene was recovered with a rabbit in the chamber. 1,8Cineol content for sagebrush alone was $0 \mathrm{mg}$, while with a rabbit, $1.14 \mathrm{mg}$ was recovered. Recoverable camphor with sagebrush alone was $0.45 \mathrm{mg}$ and with a rabbit $4.33 \mathrm{mg}$ was recovered. Unknown monoterpenoid content for sagebrush alone was 0.08 $\mathrm{mg}$ and with a rabbit was $0.05 \mathrm{mg}$. The difference between mono-

Table 2. Total recoverable monoterpenoids from an airtight rabbit chamber with and without a rabbit present. Data expressed in $\mathrm{mg}$.

\begin{tabular}{|c|c|c|c|c|c|c|c|c|}
\hline \multirow{2}{*}{ Monoterpenoids } & \multicolumn{4}{|c|}{ Sagebrush with rabbit } & \multicolumn{4}{|c|}{$\begin{array}{c}\text { Sagebrush without } \\
\text { rabbit }\end{array}$} \\
\hline & Test 1 & Test 2 & Test 3 & $\bar{x}$ & Test 1 & Test 2 & Test 3 & $\vec{x}$ \\
\hline $\begin{array}{l}\alpha \text {-Pinene } \\
\text { Camphene } \\
1,8 \text {-Cineol }\end{array}$ & $\begin{array}{r}0.14 \\
.36\end{array}$ & & $\begin{array}{l}0.07 \\
2.86 \\
3.42\end{array}$ & $\begin{array}{l}0.07 \\
1.07 \\
1.14\end{array}$ & & & & \\
\hline Camphor & 1.25 & 1.43 & 10.31 & 4.33 & 0.47 & 0.49 & 0.38 & 0.45 \\
\hline Unknowns & .07 & .03 & .04 & .05 & & .05 & .20 & .08 \\
\hline Total & 1.82 & 1.46 & $16.70^{1}$ & 6.66 & .47 & .54 & .58 & .53 \\
\hline
\end{tabular}

Test in which the rabbit was fasted 12 hours prior to testing. terpenoids trapped from sagebrush alone and from sagebrush being fed upon by the rabbit was statistically significant.

The third test, in which the rabbit was fasted 12 hours prior to testing, recovered $16.70 \mathrm{mg}$ total monoterpenoids, while with only sagebrush in the chamber $0.58 \mathrm{mg}$ were trapped.

\section{Discussion}

The individual monoterpenoids found in big sagebrush collected from Dubois, Idaho, and stomach ingesta were nearly the same. This supports the assumption that the big sagebrush sampled in the area where pygmy rabbits were killed was similar to the big sagebrush eaten by the rabbits.

Results of stomach analysis of pygmy rabbits showed a significant loss $(77 \%)$ of monoterpenoids as compared with big sagebrush from the same location.

Recent studies indicate microbial fermentation may occur in the stomach and does occur in the cecum of rabbits (Alexander and Chowdhury 1958; McBee 1971). Nagy et al. (1964) showed that the monoterpenoids of big sagebrush when in high enough concentrations, suppress the in vitro growth, cellulose digestion, volatile fatty acid production, and gas production of mule deer rumen microorganisms. These monoterpenoids could negatively interact with pygmy rabbit stomach and cecal microorganisms. It appears from this study, however, that pygmy rabbits have developed mechanisms that reduce the amount of monoterpenoids by $77 \%$ in stomach ingesta, thus greatly reducing any adverse interaction between monoterpenoids and microorganisms. Cluff et al. (1982) reported a significant reduction in the levels of monoterpenoids in the rumen of mule deer. Welch and Pederson (1981) observed that $\alpha$-Pinene and camphor were lost from the digestion solution during in vitro digestibility trials.

Three mechanisms have been proposed that could reduce the monoterpenoid level in the ingesta of the herbivore: (1) loss that occurs through clipping, mastication, and rumination by ruminants (Welch and Pederson 1981); (2) body heat during ingestion of plant material causing release through eructation (Welch and Pederson 1981); and (3) absorption through the rumen wall and into the blood where it is excreted by the kidneys (Cook et al. 1952; Freeland and Janzen 1974). Our discovery of a 77\% loss of monoterpenoids from sagebrush in the stomach contents of pygmy rabbits prompted us to test the hypothesis that monoterpenoids are volatilized during mastication and ingestion. This was tested by using an airtight rabbit chamber. Results of rabbit testing showed 12 times more recoverable monoterpenoids $(6.66 \mathrm{mg})$ were collected from air passed through a chamber with a rabbit and sagebrush in the chamber than with sagebrush alone $(.53 \mathrm{mg})$. The third rabbit chamber test, in which the pygmy rabbit was fasted 12 hours prior to testing, recovered 31 times more monoterpenoids. These results illustrate the importance of volatilization of monoterpenoids during the act of ingestion.

\section{Literature Cited}

Alexander, F., and A.K. Chowdhury. 1958. Digestion in the rabbit's stomach. Brit. J. Nutr. 12:65-73.

Braun, C.E., T. Britt, and R.D. Wallestad. 1977. Guidelines for maintenance of sage grouse habitats. Wildl. Soc. Bull. 5:99-106.

Carpenter, L.H., O.C. Wallmo, and R.B. Gill. 1979. Forage diversity and dietary selection by wintering mule deer. J. Range Manage. 32:226-229.

Cluff, L., B.L. Welch, J.C. Pederson, and J.D. Brotherson. 1982. The concentration of monoterpenoids in rumen ingesta of wild mule deer browsing on a hig sagebrush winter range. J. Range Manage. 35:

Cook, C.W., L.A. Stoddart, and L.E. Harris. 1952. Determining the digestibility and metabolizable energy of winter range plants by sheep. J. Animal Sci. 11:578-590.

Flinders, J.T., and R.M. Hansen. 1972. Diets and habitats of jack rabbits in northeastern Colorado. Range Sci. Dep. Sci. Ser. No. 12. Colorado State Univ., Fort Collins, 29 p.

Freeland, W.J., and D.H. Janzen. 1974. Strategies in herbivory by mammals: The role of plant secondary compounds. Amer. Natur. 108:269289. 
Green, J.S., and J.T. Flinders. 1980. Habitat and dietary relationship of the pygmy rabbit. J. Range Manage. 33:136-142.

Huntsberger, D.V. 1967. Elements of Statistical Inference. Allyn and Bacon, Inc. Boston, Mass., 398 p.

Kufeld, C.R., O.C. Wallmo, and C. Feddema. 1973. Foods of the Rocky Mountain mule deer. U.S. Dep. Agr. Forest Serv. Res. Pap. RM-111, 13 p.

Longhurst, W.M., H.K. Oh, M.B. Jones, and R.E. Kepner. 1968. A basis for the palatability of deer forage plants. North Amer. Wildl. and Natur. Resource Conf. Trans. 33:181-192.

McBee, R.H. 1971. Significance of intestinal microflora in herbivory. Amer. Rev. Ecol. Syst. 2:165-176.

Moir, R.J., 1968. Ruminant digestion and evolution. In: C.F. Cado (ed.) Alimentary Canal. Amer. Physiol. Soc., Washington D.C., 2673-2694.

Nagy, J.G., and W.L. Regelin. 1977. Influence of plant volatile oils on food selection by animals. XIIIth Cong. of Game Biol. 13:225-230.

Nagy, J.G., H.W.Steinhoff, and C.M. Ward. 1964. Effects of essential oils of sagebrush on deer rumen microbial function. J. Wildl. Manage. 28:785-790.

Nagy, J.G., and R.P. Tengerdy. 1968. Antibacterial action of essential oils of Artemisia as an ecological factor. II. Antibacterial action of the volatile oils of Artemisia tridentata (big sagebrush) on bacteria from the rumen of mule deer. Appl. Microbiol. 16:441-444.

Radwan, M.A. 1974. Natural resistance of plants to mammals. In: H.C. Black (ed.) Wildife and Forest Management in the Pacific Northwest. Oregon State Univ., Corvallis. 85-94.

Severson, K., M. May, and W. Hepworth. 1968. Fond preferences, carrying capacities, and forage competition between antelope and domestic sheep in Wyoming's Red Desert. Agr. Exp. Sta., Univ. of Wyoming, Laramie, Sci. Monogr. 10, 51 p.

Sundstrom, C., W.G. Hepworth, and K.L. Diem. 1973. Abundance, distribution, and food habits of the pronghorn. Wyoming Game and Fish Comm., Cheyenne. Bull. No. 15, 58 p.

Wallmo, O.C., L.H. Carpenter, W.L. Regelin, R.B. Gill, and D.L. Baker 1977. Evaluation of deer habitat on a nutritional basis. J. Range Manage. 30(2):122-127.

Welch, B.L., and E.D. McArthur. 1981. Variation of monoterpenoid content among subspecies and accessions of Artemisia tridentata grown in a uniform garden. J. Range Manage. 34:380-384.

Welch, B.L., and J.C. Pederson. 1982. In vitro digestibility among accessions of big sagebrush by wild mule deer and its relationship to monoterpenoid content. J. Range Manage. 34:497-500.

Wilde, D.B. 1978. A population analysis of the pygmy rabbit (Sylvilagus idahoensis) on the INEL site. Ph.D. Diss., Idaho State Univ., Pocatello, $172 \mathrm{p}$. 